\title{
Fauziah Mohd Taib (ed.) - Number One Wisma Putra
}

(Kuala Lumpur: Institute of Diplomacy and Foreign Relations, IDFR, 2006), hardcover, 311 pp. ISBN: 983-2220-11-4

\section{Christoph Marcinkowski IAIS Malaysia}

Number One Wisma Putra celebrates more than half a century of service to Malaysia by the country's Foreign Service. Its humble origins date back to July 1956 as External Affairs Ministry of the then Federation of Malaya, before Prime Minister Tunku Abdul Rahman Putra Al-Haj became the first Minister of Foreign Affairs in September 1957 - only ten days after independence from Britain. Today, No. 1 Wisma Putra happens to be the address of the Malaysian Ministry of Foreign Affairs in the country's new administrative capital, Putrajaya, which is only a short drive south of Kuala Lumpur, where the Ministry had its beginnings. As pointed out in the foreword by Malaysia's former Prime Minister, Tun Abdullah Ahmad Badawi, who from 1991 to 1999 served also as the country's foreign minister, 'Wisma Putra' is the popular non-official name for the Ministry, thus fondly remembering its founder Tunku Abdul Rahman, the 'Father of Malaysia's Independence'.

The book has been carefully edited by HE Fauziah Mohamad Taib, who was between 2005 and 2007 the Director General of the Institute of Diplomacy and Foreign Relations (IDFR), and who is since 2008 the Permanent Representative of Malaysia to the Organisation for the Prohibition of Chemical Weapons (OPCW) at The Hague and concurrently accredited as Malaysia's Ambassador to the Netherlands.

The book was already conceived back in 2005 by Malaysia's then foreign minister, Dato' Seri Syed Hamid Albar. He contributed also its first chapter, which is particularly charming as it provides deep insights into the often trying circumstances in which the holder of that office might find himself in his daily work. Altogether, the volume contains seven parts that are divided into 31 chapters - each of them written by a diplomat or senior civil servant of the Ministry. The chapters address in a lucid and often enchanting manner the Ministry's historical foundations, the daily life of Malaysia's ambassadors and diplomatic representatives abroad, and provide portraits of places and people in their host countries. The contributors to this volume reveal their often very personal experiences - such as what it meant to be a Malaysian ambassador in certain war zone countries, for instance in Vietnam in the early 1970s or in Saddam's Iraq during the various wars that were either initiated or provoked by him during his brutal rule. They not only provide valuable insights into the daily lives of those diplomats, but also offer information on the host countries that remain often untold in the media. Among the stories that were most interesting to this reviewer, who has some background in the study of strategic and 
Middle Eastern affairs, is the account by Fauziah Mohamad Taib (chapter 28, "The Day the World Changed", pp. 257-69), who had been Deputy Chief of Mission in Washington DC from 1998 to 2003, on the September 11, 2001 terrorist attacks on the World Trade Center in New York City, seen through her own eyes. Similarly moving are the stories by Dato' K.N. Nadarajah, Malaysian ambassador to Iraq from 1986 to 1991 (chapter 27, "Gulf Crisis: Evacuation of Malaysians”, pp. 247-55), and especially by Tan Sri Ahmad Fuzi Abdul Razak, previously Director General of IDFR and currently Ambassador-at-Large for Foreign Affairs (chapter 21, "An Encounter with Saddam Hussein”, pp. 193-201). Very valuable, too, are the insights provided by Datin Paduka Dr Rajmah Hussain, who currently serves as Malaysia's first female ambassador to the United States (chapter 29, "Reflections of a Lady Diplomat”, pp. 271-81). The fact that Sharifah Shifa Al-Attas, IDFR's Director of Research and Publication (who already has a reputation as one of Malaysia's most distinguished editors) has been behind the design of the volume's cover and layout has ensured that this book is also from an aesthetical and artistic point of view such a delight.

In sum, however, Number One Wisma Putra is not just a beautiful book that should not be missing on the shelves of those who want to know what it meant to create from scratch an efficient foreign ministry. It will also be treasured by those who want to know more about the key players, their often turbulent experiences and adventures - be it as foreign minister or as ambassadors. It is thus a fitting tribute to and celebration of the achievements and hard work that led to what Wisma Putra is today - a worldwide respected institution with now 102 diplomatic missions around the globe of a country that is also making a steadily increasing impact as a bridge between Asia and the West.

\section{David Levering Lewis - God's Crucible: Islam and the Making of Europe, 570-1215}

(New York and London: W.W. Norton, 2009), paperback, xxv +473 pp. ISBN 978-0-393-06472-8, US\$17.95

\section{Karim D. Crow IAIS Malaysia}

God's Crucible marks Lewis' historical engagement with the major theme of the impact of Islamic civilisation upon the formation of Europe. Through his synthesis of secondary historical studies in English, French and Spanish Lewis paints a broad historical canvas portraying the rise and spread of Islam in South West Asia, its dramatic extension across North Africa into the Iberian peninsula and beyond under the Umayyad Caliphs, and the complex interaction and vicissitudes of Christian and Muslim powers in Hispania/Andalusia. He ends his narrative with the start of 